\title{
A EXIGIBILIDADE DE CONDUTA DIVERSA COMO ABREVIATURA SIMBÓLICA PARA A INTEGRAÇÃO CONCRETA DE VALORES
}

\author{
THE REQUIREMENT OF DIVERSE CONDUCT AS A SYMBOLIC \\ ABBREVIATION FOR THE CONCRETE INTEGRATION OF \\ VALUES
}

Simone de $S \dot{a}^{1}$

UFPE

\begin{abstract}
Resumo
Este trabalho faz uma análise crítica acerca dos critérios atualmente utilizados pelo Poder Judiciário brasileiro na tarefa de identificação e seleção de causas supralegais de inexigibilidade de conduta diversa. Baseando-se na doutrina de Tércio Ferraz Júnior, são lançadas justificativas teóricas capazes de revelar que o alcance da homogeneidade exigida pelo sistema jurídico brasileiro torna-se possível a partir da compreensão dos julgadores sobre a função que a exigibilidade de conduta diversa exerce dentro do sistema penal, papel este de abreviatura simbólica para a integração concreta de valores. A pesquisa possui um objeto delimitado que, por sua vez, é investigado pelo método hipotético dedutivo. Contém um estudo de compilação, para que as conclusões sobre o tema possam ser comparadas a outras conclusões já produzidas sobre o assunto, elaborado a partir de pesquisas feitas por meio de fontes secundárias do conhecimento.
\end{abstract}

Palavras-chave

Exigibilidade de conduta diversa. Regra de calibração. Estado Democrático de Direito.

\section{Abstract}

This paper makes a critical analysis about the criteria currently used by the Brazilian Judiciary in the task of identifying and selecting supralegals causes of non - conduct of diverse conduct. Based on the doctrine of Tércio Ferraz Junior, theoretical justifications are launched capable of revealing that the scope of homogeneity required by the Brazilian legal system becomes possible from the understanding of the judges on the function that the exigibility of diverse conduct exercises within the penal system, a symbolic abbreviation for the concrete integration of values. The search has a delimited object that, in turn, is investigated by the

${ }^{1}$ Doutora em Direito pela Universidade Federal de Pernambuco. 
bypothetical deductive method. It contains a compilation study, so that the conclusions on the subject can be compared to other conclusions already produced on the subject, elaborated from research done through secondary sources of knowledge.

Keywords

Diverse conduct requirement. Calibration rule. Democratic state of law.

\section{INTRODUÇÃO}

Dentro da Dogmática Penal, mais especificadamente, da teoria do delito, a culpabilidade se apresenta, já há algum tempo, como elemento de relevo. O debate acerca da sua essência, do seu conteúdo, sobre a sua relação com a pena e, sobretudo, quanto à sua capacidade de limitar o poder de punir do Estado, evidenciou a riqueza e complexidade do referido elemento do crime.

A percepção da doutrina acerca dessa complexidade imanente à ideia de culpabilidade, com o passar do tempo, apenas se intensificou. Isso ocorreu, especialmente, a partir dos estudos sobre um dos seus elementos: a exigibilidade de conduta diversa.

No Brasil, atualmente, esse instituto encontra-se estabelecido legalmente apenas a partir de dois casos definidos como hipóteses de inexigibilidade de conduta diversa: a coação moral irresistível e a obediência hierárquica.

Em contrapartida, já há quase trinta anos, a partir das contribuições, notamante, de Assis Toledo, se iniciou no Brasil um processo de reflexão acerca da insuficiência da lei em relação à previsão dos casos de inexigibilidade de conduta diversa, o que, progressivamente, refletiu na alteração de posicionamento do Poder Judiciário brasileiro sobre a questão. Observando a essência do conceito de culpabilidade, houve a reflexão no sentido de que os casos em que, embora tendo praticado um ato ilícito, o agente não deveria ser reprovado por não ser exigível atuar de modo diverso, conforme o direito, não poderiam se restringir a obediência hierárquica e coação moral irresistível. 
Por conseguinte, considerou-se ser incompatível com o conceito de culpabilidade reprovar aquele que em um dado concreto não poderia agir de forma diversa, mesmo em se tratando de uma situação diferente das referidas na legislação penal como causas de inexigibilidade diversa.

Desde então, mesmo que progressivamente, os tribunais consolidaram esse entendimento, reconhecendo a possibilidade de afastar a culpabilidade com fundamento na inexigibilidade de conduta diversa como causa supralegal.

Por outro lado, apesar de todo esse contexto e de ser um instituto da dogmática penal amplamente difundido e debatido nos sistemas jurídico-penais ocidentais, no Brasil, não há uma definição precisa do que seja a exigibilidade de conduta diversa.

Tal afirmação provém do fato de serem desconhecidos os limites da consideração acerca da existência ou inexistência de exigibilidade de conduta diversa, ocasionada pela falta de racionalidade do sistema na eleição dos valores aceitos como aptos à aniquilar a liberdade, o que desemboca no obscurantismo acerca dos limites da analisada causa de exculpação.

Nesse sentido, ao passo que não são conhecidos os limites para a admissão de causas supralegais instituto, são ocultos também os contornos da exibilidade de conduta diversa em si.

A partir da análise da jurisprudência brasileira, verifica-se que os precedentes que se debruçam sobre a questão não apresentam homogeneidade em relação as balizas utilizadas para a admissão da tese da inexigibilidade de conduta diversa baseada em causa supralegal.

Não há, sequer, a indicação do caminho pelo qual o julgador deve trilhar na tarefa de identificar a ausência ou presença de situação de inexigibilidade de conduta diversa nos casos concretos eventualmente apresentados.

Há, frise-se, uma carência doutrinária e também jurisprudencial em relação ao esclarecimento acerca das bases pelas quais o judiciário deve 
se nortar ao se debruçar sobre um caso em que se questiona a existência de inexigibilidade de conduta diversa com base em uma causa supralegal.

Essa escassez tratada no parágrafo anterior tem gerado uma heterogeneidade em relação às decisões do Poder Judiciário brasileiro relativas à questão, considerada grave, posto que gera uma instabilidade indesejada em se trantando um Estado Democrático de Direito.

A ausência de indicação das balizas que devem nortear uma decisão sobre a exigibilidade de conduta diversa serve de móvel para uma sensação de insegurança que, por sua vez, torna os julgadores resistíveis a admissão da tese em casos onde a admissão seria adequada e vice-versa.

Nessa toada, este estudo visa, exatamente, alcançar as bases que os julgadores brasileiros devem observar em uma decisão que verse sobre a admissão de causas supralegais de inexigibilidade de conduta diversa, expondo, assim, os caminhos que devem ser utilizados para se obtenha uma jurisprudência com homogeneidade satisfatória a um Estado Democrático de Direito, ou seja, suficientemente harmoniosa, coesa.

Busca-se apresentar uma reflexão crítica acerca da atual postura do Judiciário brasileiro, apresentando, outrossim, a partir das contribuições teóricas de Tércio Ferraz Júnior, uma outra perspectiva de análise do problema, voltada à observação do funcionamento do sistema penal, com o objetivo de identificar a partir das características normativas da exigibilidade de conduta diversa, a sua função e, acima de tudo, as balizas que o Poder Judiciário deve utilizar no momento de sua interpretação, da decisão.

Entretanto, desta pesquisa não resultam conclusões teoricamente fechadas sobre os critérios e método legitimadores em relação à admissão de causas supralegais de inexigibilidade de conduta diversa. $\mathrm{Na}$ realidade, o intuito final é abrir, de forma crítica, novos horizontes, possibilitando, quem sabe, a introdução de bases novas, capazes de esvaziar ou ao menos diminuir a insegurança que permeia atualmente a discussão. 


\section{SOBRE O CONCEITO MATERIAL DA CULPABILIDADE NA TEORIA NORMATUVA PURA DE WELZEL E NO FUNCIONALISMO DE ROXIN}

Ao se questionar o fundamento material da culpabilidade, se analisa o motivo do Estado impor uma pena a determinadas pessoas qualificadas como culpáveis. Sua definição tende a transformar-se no argumento teleológico - baseado em considerações éticas, sociológicas ou ideológicas - que legitima o conjunto de elementos que o direito positivo concreto acolhe na posição sistemática da culpabilidade.

Esse conceito material pretende servir como critério legitimador e delimitador do jus puniendi do Estado, se convertendo, portanto, em um conceito de importância capital, visto que pode chegar a permitir desenvolver causas supralegais de exclusão da culpabilidade (AGUADO, 2003, p. 103).

A concepção atual de culpabilidade é uma construção que se inicia com a teoria normativa, apesar do termo ser bastante utilizado anteriormente, de ser entendido como sinônimo de responsabilidade.

Esse marco se justifica por apenas a partir dali a culpabilidade ser concebida como juízo de reprovação pessoal que se dirige ao sujeito que, apesar de poder cumprir as determinações das normas jurídicas, praticou uma ação constitutiva de um tipo penal, realizando, assim, uma conduta prevista como delito mesmo havendo a possibilidade de agir de forma diferente. Nesse sentido, Roda (1977, p. 16-18) acrescenta que "a culpabilidade como requisito da noção de delito constitui uma construção da dogmática jurídica submetida, como tal, ao marco representado pela lei."

Como se percebe, a partir da normatização da culpabilidade, ela é definida como um juízo de reprovação cujo pressuposto é o poder do sujeito de adaptar a sua conduta às normas do direito. Nesse momento também surge uma série de questionamentos, de observações acerca desse 
"poder", da liberdade de ação, com relação à forma da sua identificação diante dos casos concretos, aos limites do cientificamente factível.

Há culpabilidade quando a conduta do autor não é como exige o direito, pois o autor poderia realizá-la de acordo com a norma. Nessa dupla relação, de não dever ser antijurídica quando podia ser jurídica, consiste o caráter específico da censura na culpabilidade (WELZEL, 2002, p. 125).

O finalismo, fundamentando a culpabilidade na ideia de que o homem tem a possibilidade de atuar conforme o direito, acaba concebendo o referido elemento do crime como um juízo de reprovação que recai sobre a resolução da vontade, pois o autor poderia adotar, no lugar de uma resolução de vontade antijurídica, uma conforme a norma. Examinando a situação particular e o indivíduo concreto, conclui o finalismo que o sujeito culpável poderia dirigir a sua vontade no mesmo sentido do comando normativo.

A culpabilidade passa a ser um juízo de valor sobre a resolução da vontade, a qual passa a ser objeto de valoração da culpabilidade, dessa forma, o autor será censurado penalmente quando podia adotar uma resolução de vontade conforme a norma, no lugar da antijurídica.

Para o autor (2002, p. 155-156), o juízo da culpabilidade só pode censurar o sujeito que pode, com livre determinação, conhecer e dirigir seu comportamento conforme o sentido. Nessa linha, os elementos constitutivos da culpabilidade são aqueles necessários ao sujeito, para que o mesmo adote uma resolução de vontade conforme o direito. Dessa forma, a culpabilidade concreta é formada por elementos intelectuais e volitivos. Quando o sujeito não tem a possibilidade de atuar conforme o direito, seja porque lhe falta capacidade de culpabilidade (imputabilidade), seja porque há carência no elemento intelectual da culpabilidade (potencial consciência 
da ilicitude) ou seu elemento volitivo (exigibilidade de conduta diversa), o sujeito não será culpável. ${ }^{2}$

A estrutura da teoria do delito desenvolvida por Welzel perdura, com poucas alterações, até o início do século XXI, no entanto, muito controvertida, debatida, defendida e também combatida é a sua concepção de culpabilidade material, fundada num livre-arbítrio que, por sua vez, é formado a partir de "capas" de determinismo, em que o sujeito será culpável apenas quando, em uma análise retrospectiva, poderia ter atuado de outra maneira, ou seja, o sujeito é culpável quando pratica um ilícito penal na medida em que poderia, no caso concreto, ter dirigido sua vontade em conformidade com o direito e assim não o fez. Longe de tratar a questão da liberdade nos moldes clássicos, o livre-arbítrio em Welzel é

${ }^{2}$ Válido registrar a observação de Roxin (2003, p. 793) quando diz que Welzel faz diferença entre causas de exclusão da culpabilidade (por inimputabilidade e por falta de potencial consciência de ilicitude) e de exculpação (por inexigibilidade de conduta diversa), por no segundo caso não haver propriamente ausência de culpabilidade, mas sim, a sua redução a um patamar mínimo do qual deriva uma indulgência do legislador em face da debilidade humana. 


\section{DELICTAE, Vol. 4, Nº, Jul..-Dez. $2019 \mid 194$}

\section{discutido em um triplo aspecto: antropológico, ${ }^{3}$ caracterológico ${ }^{4}$ e categorial..$^{5}$}

${ }^{3}$ No aspecto antropológico, Welzel (2002, p. 135-136) diz que o homem se caracteriza negativamente pela sua liberdade em relação às formas inatas e instintivas de condutas, e positivamente pela capacidade e pela tarefa de descobrir e realizar por si mesmo a conduta correta por meio de atos inteligentes; a liberdade existencial, portanto, seria uma característica positiva e decisiva do homem, a vinculação de seu espírito a critérios de verdade, de sentido e valor. A capacidade de realizar ações finais é o primeiro requisito essencial do homem e é exatamente nessa capacidade que estão os pressupostos biológicos da desvinculação dos impulsos. Para Welzel, a diferença entre o homem e o animal impõe uma dura carga, que é a perda da segurança da vida meramente instintiva, que confere ao animal um sistema de ação para o futuro. Assim, o homem livre desta segurança instintiva, deve elaborar, por meio da educação, da autoinformação, um sistema de ações para o futuro, como ser responsável, o que o separa a existencialmente e normativamente do animal. Essa liberdade existencial e desvinculação do orgânico, do instintivo, é a carcaterística positiva e decisiva do homem.

${ }^{4}$ Quanto ao aspecto caracteriológico, Welzel (2002, p. 137-138) trata do retrocesso das formas inatas de conduta e das aparição de um "eu" (centro regulador responsável), fazendo com que a estrutura anímica do homem tenha uma pluralidade de "capas". Em um nível mais profundo, estão os impulsos de conservação da espécie, de autoconservação, desejos, aspirações anímicas e sobre esses impulsos, eleva-se o "eu" como centro regulador, que dirige esses impulsos racionalmente conforme sentido e valor. Nesse sentido, todos os impulsos, desde aqueles situados na capa mais profunda, como os que emergem do "eu" responsável, possuem um duplo aspecto: uma determinada força e um determinado conteúdo de sentido. No âmbito mais profundo, quando há contraposição entre dois impulsos, a prevalência fica-se pela força do impulso, enquanto no âmbito mais elevado que envolve o "eu" regulador, não é levada em conta apenas a força, mas também o seu conteúdo e sentido e a sua significação valorativa para uma configuração correta da vida. Os diversos conteúdos de sentido convertem-se em motivos (razões objetivas) nos quais se apoiam as respectivas decisões da vontade. Porém, são os impulsos da "capa profunda" o pressuposto material dos atos conforme o sentido.

${ }^{5}$ Em relação ao terceiro aspecto, o categorial, Welzel (2002, p. 139-145) questiona como é possível ao homem dominar a coação causal por meio de uma direção orientada a sentido, em virtude da qual, unicamente, é possível fazê-lo responsável por haver adotado a decisão errada ao invés da correta. Ressalta que a resposta não pode ser feita pelo tradicional indeterminismo, que acredita, por sua vez, nada determinar o ato de vontade, nem pelo 
A questão do livre-arbítrio surge para Welzel a partir da seguinte pergunta: como é possível o domínio da coação causal de se fazer responsável por uma certa decisão no lugar de outra? Com base filosófica, se questiona como é possível o ser humano dominar o curso causal e se fazer responsável por uma ação em face da possibilidade de realizar outra, indicando como caminho para a resposta reflexões sobre o ato de conhecer.

Nesse sentido, segundo o autor, o ser humano é composto por vários estratos. Há estratos inferiores, chamados de reguladores biológicos, que são formas inatas, instintos, emoções, que não diferenciam o homem do animal que, por sua vez, influenciam as demais capas (superiores).

O que diferencia o homem dos animais, portanto, é a razão, é a capacidade de dominar os impulsos causais dando motivo para os mesmos em face do "eu". O "eu" é que dá sentido aos impulsos causais (tarefas plenas de sentido ou a partir de um sentido), sendo influenciado pelas capas superiores apesar de ser capaz de se livrar desses impulsos causais uma vez o que o ser humano pode agir de forma inteligente (dando sentido às suas ações), que pode conhecer não só a si mesmo, mas também as estruturas lógico-objetivas das coisas.

Segundo Welzel, em face da razão, o ser humano tem capacidade de conhecer a essência das coisas e, por isso, por conhecer as estruturas lógico-objetivas dos objetos, pode conhecer a própria realidade.

determinismo tradicional, que crê na existência de apenas uma forma de determinação (monismo causal). Prega que há concorrência de várias formas de determinação. No entanto, o sujeito cognoscente não deve ser apenas objeto do jogo dos seus impulsos, mas tem que ter capacidade de compreender o impulso do conhecimento como uma tarefa plena de sentido, que deve ser afirmada ante os impulsos contrários. Dessa forma, o homem será responsável pelo impulso do ato de conhecimento, e a liberdade de vontade, pois, será a possibilidade de reger-se conforme o sentido, ou seja, a liberdade não é a possibilidade de eleger arbitrariamente entre o que tem sentido e o absurdo, entre o valor e o desvalor, pois a liberdade não é um estado, mas sim um ato, ato este de liberação da coação causal dos impulsos para a autodeterminação conforme um sentido. 
Assim, Welzel acredita que o ser humano pode quase que tocar a realidade, que a linguagem é apenas uma forma de intermediar o conhecimento do ser humano e a modulação disso em som seria capaz de dizer exatamente a realidade das coisas, havendo, portanto, a exata correspondência entre objeto e linguagem. Percebe o ser humano como sujeito pleno (fundo antropológico), capaz de conhecer a realidade das coisas e de agir não por simples impulsos causais, mas com sentido, com significações.

O conhecimento das estruturas lógico-objetivas leva à ideia de que os atos de pensamento, de conhecer, são atos que não estão a depender de cursos causais, uma vez que são derivados da estrutura lógico-objetiva dos objetos, dessa forma, eles não ficam condicionados pelos estratosinferiores (como o ser humano pode conhecer essas estruturas lógicoobjetivas que existem independente do tempo, pode conhecer a realidade, chegar à essência das coisas, não pode ser considerado produto dos seus impulsos causais).

Os pensamentos seriam independentes, videntes e determinariam a si mesmos, uma vez que não estão submetidos apenas ao sujeito, mas o ato de conhecer pressupõe também as estruturas lógicoobjetivas das coisas que, por sua vez, é algo que está fora do sujeito (porém, é evidente que o sujeito também interessa pois os reguladores biológicos também influenciam).

Welzel não adota um total indeterminismo pois as estruturas lógico-objetivas das coisas, a essência dos objetos (que para ele é possível se chegar, isso, dentro da filosofia da linguagem) constituem uma limitação. $\mathrm{O}$ indeterminismo é limitado posto que se fosse ilimitado Welzel diria que o ser humano, por si mesmo, teria pensamentos independentemente de causas. Ao contrário, ele defende que os estratos inferiores condicionam os seres humanos, que fazem parte do inconsciente.

A diferença é que o ser humano pode racionalizar os estratos inferiores mesmo sendo influenciado por eles uma vez que a razão permite que o ele conheça os objetos, as estruturas lógico-objetivas do mundo, a 
realidade, dessa forma, é determinado por isso, pelo conhecimento não estar só condicionado pelo sujeito, mas também pelas estruturas lógico-objetivas das coisas.

Se o sujeito age puramente por impulso causal, não há ação para o Direito Penal, por isso, de forma figurada, se diz que a causalidade é cega e a finalidade é vidente.

Welzel conceitua a culpabilidade como a falta de autodeterminação conforme o sentido em um sujeito que era capaz de têla. Não é a decisão em si mesma, mas sim o fato do ser humano deixar-se arrastar por impulsos contrários ao valor. Portanto, a culpabilidade não seria uma livre decisão em favor do mal, ela consiste no fato do sujeito deixar-se prender pela coação causal dos impulsos, sendo capaz de determinar-se conforme o sentido. Conclui, dessa forma, que a culpabilidade não é um ato de livre determinação, senão precisamente a falta de uma decisão conforme o sentido em um sujeito responsável (WELZEL, 2002, p. 164). Assim, em face dessa capacidade de autodeterminação conforme um sentido, o finalismo pressupõe a imputabilidade, como capacidade de culpabilidade, no sentido referido de capacidade de compreensão do injusto e capacidade de determinação de vontade conforme o sentido.

Nesse diapasão, é possível dizer que a estrutura da culpabilidade é delineada da seguinte forma: a culpabilidade é a reprovabilidade do fato antijurídico individual, cujo pressuposto existencial é a capacidade de autodeterminação livre (conforme um sentido) do autor, ou seja, sua imputabilidade. A culpabilidade individual termina sendo a concreção da capacidade de culpabilidade em relação ao fato concreto individual. A reprovabilidade se refere a uma conduta antijurídica real, ou seja, se arrima nos mesmos elementos concretos em cuja a concorrência geral constitui a capacidade de culpabilidade: o autor terá que conhecer (efetiva ou potencialmente) o injusto do fato concreto, bem como ter a possibilidade de decidir por uma conduta conforme o direito nas circunstâncias do caso concreto. Assim, a reprovabilidade concreta é formada, da mesma forma que a imputabilidade, de elementos intelectuais e volitivos, sendo a 
consciência real ou potencial da ilicitude o elemento intelectual da culpabilidade e a exigibilidade de obediência ao direito o seu elemento volitivo (MELLO, 2010, p. 164-165). ${ }^{6}$

A culpabilidade formal para Welzel compreende os elementos do fato que, em uma ordem jurídica determinada são exigidos positivamente como pressupostos para a imputação, ou seja, consiste na totalidade dos componentes intelectuais e volitivos que são considerados normativamente como requisitos para a imputação pessoal. Já a culpabilidade material, objeto do presente estudo, se fundamenta na possibilidade do homem concreto atuar conforme o direito quando atuou de maneira contrária ao mesmo. Trata-se da possibilidade de atuar de outro modo, forma esta compatível com o direito que, por sua vez, é algo centrado em uma ideia de liberdade de vontade que sustenta a reprovabilidade da conduta antijurídica. Este é conteúdo material da culpabilidade finalista que, inclusive, representa o ponto de partida das teorias contemporâneas da culpabilidade, seja para reafirmar a ideia de liberdade, seja para negá-la, em razão da sua inverificabilidade empírica.

Baseia-se, portanto, na ideia de liberdade de vontade e considera como pressuposto fundamental da responsabilidade o poder atuar de outro modo. Assim, as causas que excluem a culpabilidade devem encontrar como fundamento a ausência, no autor, da dita possibilidade de atuar de outra forma (PUIG, 2006, p. 162).

A exigibilidade de outra conduta, por conseguinte, "debruça-se sobre a liberdade do agente que o reprova pelo mau uso da dita liberdade, a saber: o agente é censurado por ter escolhido se comportar contrário ao

${ }^{6}$ Os critérios jurídicos fundamentais da culpabilidade fluem diretamente das determinações antropológicas básicas do homem como ser atuante e conformador de seus impulsos. Firmam-se, assim, como elementos da culpabilidade: a imputabilidade, a consciência real ou potencial da ilicitude e a exigibilidade de conduta diversa, os quais continuam sendo utilizados mesmo no início do século XXI (MELLO, 2010, p. 165). 
direito, quando podia se comportar conforme o direito." (BRANDÃO, 2005, p. 224)

No mesmo sentido, Dias (2011, p. 65) diz que a culpabilidade da vontade na teoria de Welzel é uma culpabilidade da vontade potencial, em que o comportamento ilícito será culpável sempre que o agente individual seja, concretamente, capaz de se deixar determinar pelo dever jurídico de atuar de acordo com a norma.

Em face das dificuldades de se constatar exatamente a culpabilidade, se questiona se esse conceito não deve ser substituído pela verificação da necessidade da pena com base na política criminal, de prevenção geral e especial, sob a promessa de com isso não serem restringidas os aspectos garantistas da culpabilidade normativa, lembrando ainda, que a doutrina do livre-arbítrio não impede a existência de abusos. ${ }^{7}$

Segundo Roda (1977, p. 33), com a eliminação da culpabilidade e sua substituição pela exigência referente à necessidade da pena, não se pretende de modo algum abandonar o conjunto de garantias em favor do indivíduo centradas no rechaço de toda responsabilidade objetiva ou pelo resultado (...) Não se persegue por em perigo o conjunto de princípios de cunho liberal e relacionado às características da pessoa humana aos que a concepção da culpabilidade respondia. Se aduz, assim, a existência de sistemas jurídicos-penais, tais como os dos países escandinavos e anglosaxônicos, nos quais a falta da ideia de culpabilidade não gera abusos do direito de punir e, por outro lado, a manutenção da doutrina do livre-arbítrio

\footnotetext{
7 Segundo Aguado (2003, p. 80 e 81), ante os questionamentos em torno do livre-arbítrio, a doutrina tem adotado diversas posturas com critérios distintos para a fundamentação do conceito material de culpabilidade. As teorias que concebem a culpabilidade como acessibilidade normativa, a teoria da motivação e a teoria funcional da culpabilidade abandonaram a ideia de reprovação, ao menos explicitamente, e tendem a converter em atributividade, responsabilidade ou motivação. O problema do livre-arbítrio é evitado, fixado como elemento alheio a discussão ou, simplesmente, dispensando.
} 
não impede, em contrapartida, em outros sistemas jurídicos tais como o espanhol, a aparição dos referidos abusos.

Das críticas em reação à teoria finalista da ação, especialmente, com relação a indemonstrabilidade do livre-arbítrio, notadamente na década de 60 do século passado, se inicia um processo de renormatização do pensamento jurídico-penal. Há o afastamento da pretensão de, com base no mundo do ser, criar, por meio de conceitos ontológicos, das estruturas lógico-objetivas (pré-jurídicas, consideradas vinculantes ao legislador), o sistema analítico do crime. Eis o surgimento do funcionalismo. ${ }^{8}$

Neste estudo, dada a maior repercussão da sua teoria no Brasil, inclusive, com relação à problemática abordada analisaremos apenas a teoria funcionalista de Roxin que, por sua vez, não entende a culpabilidade como fundamento ou medida da pena, mas apenas como limite.

8 A nomenclatura "funcionalismo" é adequada à essa corrente visto que nela busca-se que os conceitos básicos da teoria do crime (tipicidade, antijuridicidade e culpabilidade) sejam desenhados de acordo com suas respectivas funções dentro do Direito Penal. Para o funcionalismo, o conteúdo das categorias do sistema dogmático deve ser definido em função do que se apresente mais adequado ao sistema social em geral ou a um subsistema social, como o subsistema Direito Penal. Os referidos conceitos devem ser criados a partir desse método orientado a partir das funções desempenhadas nos sistema para que possam cumpri-las da melhor forma possível, fazendo com que o Direito Penal obtenha êxito como sistema de controle social, assegurando, assim, que as expectativas normativas que demarcam o papel de cada pessoa, não sejam frustradas. Busca-se, portanto, fazer com que o sistema penal permaneça estável e que além disso, que os elementos do crime não operem de forma independente, isolada, mas sim, de forma atrelada num mesmo sentido, com o mesmo norte, com o objetivo central de fazer com que o Direito Penal realize as finalidades propostas baseado nas teorias preventivas da pena, guiando com eficiência a políticacriminal que se dispõe a desenvolver. Nesse sentido, a justificativa ou razão da existência das correntes funcionalistas, que tem em comum apenas o método neokantista, é a pretensão de se construir a teoria do crime por meio de conceitos formulados a partir da missão político-criminal do Direito Penal e as finalidades da respectiva teoria da pena.

${ }^{9}$ De início, é necessário esclarecer que diferente do neokantismo, onde havia a ausência de um valor hierarquicamente superior que orientasse a construção da pirâmide sistêmica e ordenasse os demais valores e finalidades (causa do desencadeamento de uma liberdade de 
Diferente de Welzel, diz que a culpabilidade, apesar de ser um conceito que detém dimensões teológicas, filosóficas e sociológicas, deve ser observada do ponto de vista jurídico, já que não importam os conceitos de culpabilidade de outras disciplinas, muito menos da metafísica, não sendo o juiz representante de qualquer divindade, uma vez que os seus julgamentos éticos não são mais valiosos do que o qualquer outro cidadão, assim, em relação à culpabilidade é necessário determinar sob que pressupostos e em que medida alguém pode ser responsabilizado por um comportamento socialmente lesivo de maneira que se lhe apliquem sanções desse ramo de direito (ROXIN, 2004, p. 48).

Para o autor, o importante não é a discussão sobre a possibilidade real o sujeito agir, concretamente, de outra forma, mas sim, saber o que o sistema jurídico exige do autor com relação à sua natureza e circunstâncias externas do evento em relação a outras pessoas, ou seja, quais as exigências endereçadas ao indivíduo de forma que se torne legítimo a imputação do fato.

De início, trata da tensão existente entre Direito Penal e a política criminal. Lembra a ideia de Liszt de que o Direito Penal é a barreira instransponível da política criminal, uma vez que o Direito Penal consiste em um sistema de garantias do indivíduo frente ao poder de punir do Estado e a política criminal se apresenta como medidas empíricas para o combate da criminalidade. Diz que essa clássica lição, onde o Direito Penal e política criminal estão em polos opostos, não deve mais prevalecer.

criação dogmática que colocou em risco o tratamento uniforme dos casos penais), no funcionalismo adota-se um valor ou uma finalidade como norte para a construção de todos os conceitos e níveis analíticos do Direito Penal (os conceitos estão vinculados uns aos outros pelo fato de se voltarem à uma mesma finalidade). $\mathrm{O}$ apoio nas ciências sociais também merece destaque como característica do funcionalismo visto que há uma preocupação de ligar o sistema penal às ciências sociais (sobretudo à sociologia sistêmica) de forma que o sistema jurídico funcione como mecanismo pelo qual se controla a atuação das pessoas segundo expectativas estampadas nas normas, dentro de um sistema mais abrangente, que é o sistema social (ZAFFARONI, 2000, p. 368). 
Roxin observa nessa tensão um grande problema, diz que existem decisões sistematicamente perfeitas mas, no entanto, politicamente ruins e, por isso, acrescenta à teoria do crime questões relacionada à pena a partir das necessidades estatais, ou seja, aos fins da pena. ${ }^{10}$

A fim de eliminar uma relação contraposta entre política criminal e Direito Penal, Roxin (2000, p. 20) diz que é necessário deixar as decisões valorativas político-criminais introduzirem-se no sistema do Direito Penal de modo que a fundamentação legal, a clareza e previsibilidade, as interações harmônicas e as consequências detalhadas desse sistema não fiquem a dever nada em relação à versão formalpositivista de proveniência lisztiana. Submissão ao direito e adequação a fins político-criminais não podem se contradizer, mas sim, devem ser unidas em uma síntese.

Nesse sentido, na relação entre dogmática penal e política criminal, onde Liszt observa diferença e constante tensão, Roxin propicia a convergência, a partir da abertura à possibilidade da dogmática permitir ser permeada e definida pela missão do Direito Penal como instrumento de política criminal: a prevenção delitiva.

Roxin (1981, p. 60-72) defende que é necessário superar, inevitavelmente, o fundamento "pode atuar de forma diversa", visto que é absolutamente indemonstrável, e propõe questionar os fundamentos da culpabilidade a partir de outro foco: do por que se exige do autor outra conduta. É necessário questionar, portanto, os motivos pelos quais o legislador, desde pontos de vista jurídico-penais, queira tornar o autor em questão responsável pelo fato apurado, não se tratando, assim, de apurar a culpa, mas a responsabilidade. A responsabilidade, porém somente pode ser apreendida a partir de pontos de vista de política criminal, associados, de algum modo, à necessidade jurídico-penal de sancionar o caso concreto.

10 Válido ressaltar desde já que não são inseridas reflexões ou exigências de natureza sociológica, da criminologia, da política, para enriquecer o sistema penal, mas tão-somente questões relacionadas às necessidades estatais, com fins preventivos. 
Para contornar a indemonstrabilidade do livre-arbítrio e a vinculação da culpabilidade a valores, núcleo da ideia de reprovabilidade, Roxin (1981, p. 182) redefine a culpabilidade em face das demais categorias do crime. Diz que a "culpabilidade" estaria relacionada à pergunta se do ponto de vista penal uma sanção contra um indivíduo concreto é ou não necessária e não se um comportamento diverso era possível, ou seja, o injusto decide quanto ao problema de ser um comportamento adequado ao Direito Penal e a "culpabilidade" responde a questões de natureza políticocriminal, relativas à necessidade de imposição de uma sanção penal aos casos concretos. ${ }^{11}$

Além de criticar a ideia de livre-arbítrio, no sentido de que se trata de um conceito metafísico indemonstrável, acrescenta que a culpabilidade não seria fundamento ou medida da pena, mas sim o seu limite. O que mede a pena, portanto, é a necessidade de prevenção especial (não a geral que, por sua vez, serve para excluir a responsabilidade), de ressocialização. Diz que Welzel no momento em que analisa a culpabilidade, não verifica o sujeito em si mas o "homem médio" e isso consiste em um prejuízo já que a culpabilidade é um juízo de reprovação pessoal naquela teoria, portanto, idealmente, teria que se reprovar o sujeito em si e não uma "ficção", mas isso não é possível exatamente porque o livre-arbítrio é um conceito metafísico, indemonstrável. ${ }^{12}$

Considera, nesse sentido, que os conceitos de dignidade humana e autonomia do homem autorizam concebê-lo como ser capaz de responsabilidade e de culpa, reconhecendo a opção da ordem jurídica pela

11 Por isso, diz que deixa de falar em culpabilidade, substituindo o termo por responsabilidade.

12 Apesar de se considerar que Freudenthal é o único autor que defende um critério individualizador, no sentido de exigir que se "entrasse na vida do indivíduo" para se constatar a culpabilidade, defende-se que na teoria de Welzel não há o reconhecimento dessa impossibilidade, posto que este entende que há a análise concreta, individual, do autor na verificação da imputabilidade. 
concepção, ainda que ficcional, de ser humano livre, de tal modo que a ideia de liberdade tem íntima relação com o conceito de culpabilidade.

Inova, portanto, em seu conceito de categoria que representa a reprovação ao autor, propondo que a categoria culpabilidade seja substituída pela categoria denominada responsabilidade, que, por sua vez, deve incluir a culpabilidade, com os elementos que lhe são conhecidos, e somar-se à necessidade da pena. Resultado dessa fórmula é que onde há a desnecessidade de pena, ou seja, onde a aplicação da pena não resta justificada, mesmo estando presentes a correta compreensão do fato praticado por parte do autor, não se justifica o reconhecimento da existência do crime.

A responsabilidade, como categoria conceitual que inclui a culpabilidade com elemento necessário, faz uma ponte com as teorias preventivas da pena, ao condicionar a punibilidade do agente à existência de efetiva necessidade preventiva de aplicação da pena, havendo, assim, a união da teoria do crime com as finalidades da pena pois, muito embora os elementos do crime sirvam como pressupostos para a imposição da pena, curiosamente, a dogmática penal se desenvolveu de forma independente dessas finalidades sobre as quais figuram como pré-requisitos. Por isso, considera-se que na teoria de Roxin há a superação desse distanciamento.

Como se percebe, em relação aos pressupostos para a responsabilização do ponto de vista penal, aponta a exigência de existência de culpabilidade e necessidade preventiva da pena (deduzida da lei). Para tanto, Roxin (2003, p. 761) defende a existência de uma relação de limitação recíproca entre culpabilidade e prevenção. Trata-se de uma teoria dialética, que surte efeitos na própria estrutura da teoria do delito pelo motivo da culpabilidade deixar de ser um elemento autônomo ao se transformar em uma parte de um conceito maior, o de responsabilidade, como juízo de valoração que pode fazer uma pessoa ser considerada penalmente responsável. Por conseguinte, a existência de apenas um dos requisitos antes apontados não basta para a existência de responsabilidade pena, sendo imprescindível a presença da culpabilidade e também da necessidade de 
prevenção para que o autor de um ilícito seja considerado responsável e, consequentemente, merecedor de uma pena, ou seja, a necessidade preventiva não substitui o requisito de culpabilidade nem o transforma numa função sua, já que prevenção e culpabilidade são requisitos distintos, que se limitam mutuamente, sendo que a necessidade preventiva da pena se apresenta como um requisito adicional à responsabilidade, como garantia suplementar do cidadão contra o excesso punitivo do Estado, representando um alternativa à pena retributiva e o seu caráter moralizante. “ (...) A culpabilidade e as necessidades de prevenção limitamse reciprocamente e somente em conjunto dão lugar à 'responsabilidade' pessoal do agente, que desencadeia na imposição da pena" (ROXIN, 2003, p. 204).

A necessidade preventiva da pena é, portanto, definida como requisito da responsabilidade, por Roxin considerar que a culpa não legitima a pena por si só, já que isso apenas seria possível se fosse adotada uma ideia retributivista da pena, o que seria incompatível com um Direito Penal tido como ultima ratio em relação à proteção de bens jurídicos. Sustenta que a pena retributiva fracassa em relação à tarefa de definir um limite, quanto ao conteúdo, ao poder punitivo estatal deixando obscuros os pressupostos de punibilidade por seus fundamentos (baseados na ideia de livre-arbítrio) não estarem comprovados, sendo irracionais e não vinculantes. Sendo assim, a culpa só poderia ser capaz de justificar a imposição da pena no domínio do indispensável por motivo de prevenção geral e enquanto não for capaz de impedir que a execução da pena se conforme ao aspecto da prevenção especial.

Roxin diz que no excesso culposo na legítima defesa por perturbação, medo ou susto há tipicidade, antijuridicidade, imputabilidade, potencial consciência da antijuridicidade e também poderia ser exigido comportamento diverso, isso inclusive no estado de necessidade exculpante, mas não há crime porque há a ausência da necessidade de se aplicar a pena, de ser reforçada a confiança dos súditos no ordenamento jurídico, excluindo nitidamente a ideia de culpabilidade como fundamento da pena. 
Sustenta, por conseguinte, que o legislador isenta de pena pessoas em situações de culpabilidade, como o estado de necessidade exculpante, em razão de aspectos preventivos, isso, com o objetivo de justificar a falta de inclusão da prevenção geral como categoria integrante da responsabilidade. Essas situações, para o autor, eram tratadas incorretamente por Welzel como sendo causas de exculpação e não como causas de exclusão da culpabilidade. Segundo o autor, tal distinção não deve proceder pois existem determinadas zonas nas quais há culpabilidade diminuída, casos em que seria recomendável também a renuncia do Estado ao direito de punir. Além disso, as causas de exculpação, em verdade, pertencem à outra categoria da responsabilidade que é a da prevenção, assim, a chamada "exculpação" seria uma hipótese em que o legislador reconhece a culpabilidade, no entanto, renuncia à imposição da pena por a mesma não ser preventivamente necessária. É exatamente quanto a esse ponto que a doutrina visualiza certa vantagem da teoria de Roxin, no sentido de que o reconhecimento de que a culpabilidade e prevenção ocupam o mesmo nível na condição de pressuposto da responsabilidade penal faz com que haja evidente conexão do conceito de responsalidade com a teoria dos fins da pena, podendo o juiz, dessa maneira, excluir a responsabilidade penal quando a pena não fosse mais preventivamente necessária (MELLO, 2010, p. 234).

Roxin rebate críticas no sentido de que essa possibilidade supostamente aberta de isenção de pena geraria insegurança jurídica ou a possibilidade indiscriminada de sentenças absolutórias. Diz que a interpretação do direito não concede aos juízes o poder de isentar de pena de acordo com suas próprias convicções político-criminais, mas sim, analisar as hipóteses preventivas que servem de base à lei. Argumenta também que as interpretações sobre as necessidades preventivas não geram mais espaço do que em outros casos semelhantes em que se dá ao julgador a possibilidade de desenvolver a dogmática penal. A inclusão de necessidades preventivas como requisito adicional da culpabilidade submete-se ao mesmo tipo de crítica que pode existir, por exemplo, a tipos 
penais abertos, em que há uma ampla margem de discricionariedade judicial para a concretização do direito. A necessidade preventiva estabelecida pela lei não pode ser substituída pela necessidade preventiva pessoal e arbitrária do juiz, a partir de seu critério pessoal de justiça.

Em sua teoria, a culpabilidade possui dois elementos: um empírico e um normativo. Roxin a define como capacidade (elemento empírico) de decidir se dirigir conforme as normas (elemento normativo). É, assim, a capacidade de auto-direção, algo comprovado pela psicologia e psiquiatria. ${ }^{13}$

O fundamento material da culpabilidade, como se percebe, em Roxin é a atuação injusta em que pese a existência de uma dirigibilidade normativa, assim, o sujeito é culpável quando, ao praticar o fato estava disponível para atender ao chamado normativo em face de seu estado mental e anímico, não tendo relevância a vontade de orientar-se por uma postura determinista ou indeterminista pois o que tem importância é a possibilidade de decidir por uma conduta orientada de acordo com a norma. Nesse sentido, a culpabilidade é considerada um conceito misto, de natureza empírica, pois a capacidade de autocontrole e de reagir a exigências normativas podem ser comprovadas a partir das regras da experiência, e normativa, porque a possibilidade de atuação conforme o direito é apreensível num processo penal concreto a partir daqueles dados empíricos. Se o autor tem a capacidade para reagir ao estímulo normativo, imagina-se que tem também de se comportar conforme o direito, sendo culpável quando não se comporta conforme nenhuma das alternativas possíveis de comportamento que the são psiquicamente acessíveis para evitar o cometimento do ilícito, ou seja, em Roxin, a culpabilidade é formada pela soma de dois elementos: a capacidade de autocontrole, como elemento

${ }^{13}$ Mesmo sendo enfático em relação à essas ideias, Roxin não cita nenhum autor da área e nem informa como comprovar essa capacidade de se auto-dirigir. 
empírico, e a possibilidade de conduta conforme a exigência do direito, como elemento normativo. (MELLO, 2010, p. 239)

O fundamento da culpabilidade para Roxin é a função motivadora da norma penal, função que no sistema penal é realizada pela pena, razão pela qual, ausente a necessidade de pena, falta razão motivadora para o reconhecimento da reprovação e não pode haver responsabilidade, mesmo ante a existência de culpabilidade. Assim, a estrutura do conceito de delito, para Roxin, traz a categoria responsabilidade no lugar do tradicional conceito de culpabilidade. E, como dito, dentro da responsabilidade, se encontram como elementos a culpabilidade e a necessidade de pena. A culpabilidade, por sua vez, como elemento da responsabilidade, é composta por imputabilidade, potencial consciência da ilicitude e exigibilidade de outra conduta.

Assim, diferente do finalismo, onde a culpabilidade é o fundamento da pena, onde a pena é uma resposta à ação culpável, no funcionalismo, a culpabilidade é retirada do fundamento da pena e inserida no campo da política criminal, a saber, a sua necessidade preventiva, contrariando frontalmente a histórica definição de pena referida a um atributo do autor (livre-arbítrio) ou de sua ação (reprovabilidade). Nesse diapasão, culpável é aquele que poderia se submeter à expectativas normativas e assim não o fez, melhor dizendo, responsável é o culpável a quem a imposição da pena é funcional, ou seja, atende às finalidades de prevenção geral positiva. $E$ isso não quer indicar a possibilidade de se renunciar à reprovabilidade individual, mas sim, que esta passou de um requisito da punibilidade necessário e suficiente para um pressuposto necessário da mesma.

\section{SOBRE A INVIABILIDADE DA ADOÇÃO DE CRITÉRIOS RÍGIDOS PARA A DEFINIÇÃO DO INSTTITUTO DA EXIGIBILIDADE DE CONDUTA DIVERSA}


A tensão entre valores não é um fenômeno pontual em relação as decisões judiciais que se debruçam sobre a admissão de causas supralegais de inexigibilidade de conduta diversa.

É possível afirmar que toda decisão que versa sobre esse instituto trabalha conscientemente ou inconscientemente, explicitamente ou implicitamente com conflito de valores e que qualquer investida no sentido de elencar quais valores devem se sobressair nas decisões é completamente inútil.

Em verdade, é interessante nesse momento lembrar que todas as tentativas no sentido de se estabelecer critérios rígidos ou específicos para a constatação da inexigibilidade de conduta diversa foi passível de críticas bem fundamentadas.

Essa tarefa, do ponto de vista teórico, e tão somente teórico, talvez fosse até possível. No entanto, levando em consideração que o Direito Penal é construído e lapidado com o fim de solucionar as mais diversas situações que a experiência apresenta, uma definição dessa natureza não teria utilidade.

A cada dia, essa mesma sociedade em que o Direito tem por objetivo satisfazer, se torna sempre mais complexa. Com o passar do tempo, surgem mais valores e, assim, acaba por existir uma relação cada vez mais intensa entre os mesmos.

Dada a diversidade com que se apresentam esses valores, em uma relação cada dia mais acentuada, há, consequentemente, o aumento da divergência em detrimento da convergência nessa relação, aumentando, assim, quase que naturalmente, os conflitos.

Nesse sentido, há, concomitantemente, àquele responsável pela solução dos conflitos, uma demanda cada vez maior e também mais complexa. Por conseguinte, existe, para o Direito e seus aplicadores, uma maior exigência em relação a tomada de decisões, tanto em relação ao aspecto quantitativo como qualitativo uma vez que fundamentações simplistas, que dispensam uma análise mais profunda e detida acerca dos institutos jurídicos, se tornam insuficientes. 
Assim, ao mesmo tempo em que existe um aumento de demanda perante o Poder Judiciário por vários fatores, inclusive, pelo crescimento progressivo da complexidade da sociedade, há, simultaneamente, a necessidade, também cada vez maior, de uma análise mais acurada, mais reflexiva, com relação a aplicação do Direito aos casos concretos.

Esse crescimento da complexidade de valores que permeiam a sociedade evidencia, ainda mais nitidamente, a insuficiência do Direito escrito em relação a difícil missão de solucionar todos os casos concretos levados ao Poder Judiciário.

Como se sabe, mesmo no plano hipotético, a ideia de que o Direito escrito pode ser suficiente para a solução dos casos concretos se apresenta como equivocada. Ante a percepção desse aumento progressivo de valores diferentes ou reinterpretados distintamente e, consequentemente, da divergência que pode se afigurar entre os mesmos (nos casos concretos), a utilização não exclusiva da lei escrita ou a consciência sobre a insuficiência de interpretação exclusivamente formal da mesma para decidir demandas aparece como algo inevitável.

Ocorre que, mesmo partindo da compreensão de todo esse contexto, há, em contrapartida, a necessidade compatibilizar essa maior liberdade nas decisões do Poder Judiciário com as bases gerais do sistema jurídico utilizado.

É de conhecimento que o respeito legalidade serve como verdadeiro termômetro em relação à existência de um Estado Democrático de Direito. E, em relação as causas supralegais de inexigibilidade de conduta diversa, é também sabido que a doutrina converge no sentido de que teleologicamente essas decisões são compatíveis com o princípio da legalidade, uma vez que aumentam o âmbito de liberdade dos cidadãos.

Mas, como dito, nos propomos a ir um pouco mais além ao fazer uma crítica com relação a legitimidade das decisões que acatam ou rejeitam causas supralegais de inexigibilidade de conduta diversa. Isso porque dentro de um Estado Democrático de Direito, é também necessário 
que, em relação à institutos penais, notadamente, àqueles que compõe o conceito de crime, hajam contornos um tanto quanto definidos que resultem em um mínimo de homogeneidade em relação às decisões judiciais.

Esclareça-se que essa percepção não se confunde com a ideia simplista e, infelizmente, atual por parte do Poder Judiciário, de que é necessário muito rigor para se considerar presente uma causa de inexigibilidade de conduta diversa, exigindo a apresentação de um conteúdo probatório quase que utópico.

De antemão, é interessante registrar que a referida postura do Poder Judiciário é bastante arriscada por aumentar o risco grave de que inocentes sejam considerados criminosos. E que também não é desejável um pensamento completamente invertido, ou seja, que pessoas reprováveis sejam consideradas inocentes, perspectiva esta possível também quando não se encontra minimamente delineado um instituto de tal natureza.

À propósito, ao tratarmos do conceito de inexigibilidade de conduta diversa, optamos por utilizar os termos, "delinear", "caracterizar", sempre minimamente, porque entendemos que uma definição simples ou rígida não é possível, notadamente, nessa sociedade complexa em que vivemos.

É de conhecimento que, desde de Carrara, um dos primeiros autores de grande importância para o aprimoramento do Direito Penal, a ideia de livre-arbítrio foi considerada condição para se considerar existente a ideia de crime e também questionada pela pelos mesmo motivo das críticas atuais: a indemonstralidade desse conceito.

Dessa forma, desde a inclusão sistemática desse conceito na ideia de crime, críticas ou questionamentos, com conteúdo muitas vezes coincidente com as atuais, com relação à sua indemonstrabilidade, em paralelo, também existiam.

Em contrapartida, justificativas para esses questionamentos ou contraposições às críticas também se constituíram uma constante. O próprio Carrara, inclusive, expôs em uma importante nota de rodapé da sua obra que, apesar da liberdade de opção como potência, como conceito 
abstrato, ser indemonstrável, por ser um conceito não relativizável, gradruável, é possível que haja essa demonstrabilidade a partir de uma análise concreta, a partir da verificação da existência de alguma força ou circunstância que retira a possibilidade de opção, sendo assim, passível de graduação, de valoração (CARRARA, 1889, p. 119). ${ }^{14}$

No "vai e vem" da inclusão do livre-arbítrio como condição para se considerar inexistente ou existente a ideia de crime, surgem também, nesse mesmo sentido e de forma tautocrônica, os questionamentos sobre a demonstrabilidade desse conceito.

Vale destacar que a utilização do livre-arbítrio como elemento central na teoria do crime, possui estreita relação com o cenário político da época. A utilização de critérios exclusivamente normativos por parte do Estado, na figura dos seus representantes, se afigura como um risco ao abuso desse mesmo poder, fazendo surgir, em maior ou menor proporção, a necessidade de inclusão de critérios ontológicos. Dessa forma, a utilização de critérios dessa natureza tem notável relação com cenários políticos de crise, de excessos em relação ao exercício de punir, servindo, por conseguinte, como importante elemento limitador desse mesmo exercício.

Concomitantemente às censuras acerca da indemonstrabilidade do conceito de livre-arbítrio, de liberdade no sentido ontológico e, por

14 "Quando consideramos a a liberdade no momento de se manifestar e de se converter em determinação (arbítrio), é certamente suscetível de mais ou de menos segundo que a mônada potencialmente livre sofra no momento de ter lugar a determinação, a pressão de um número maior ou menor de forças internas ou externas que a impelem a determinar-se em um sentido mais bem do que em outro. Do mesmo modo, a inteligência é indivisível quando a consideramos como potência, pois o homem ou é inteligente ou não é. Mas, quando essa potência chega a se manifestar, se converte em compreensão (intelecto), se torna suscetível de, mais ou menos, segundo as causas internas ou externas que perturbam mais ou menos suas operações. Considerada a potência em si mesma é uma, ou existe ou não existe. Mas quando em contato com os objetos exteriores e se converte em ato, sofre para mais ou para menos, para a que a condena sua relação com os objetos individuais." (CARRARA, 1889, p. 119) 
conseguinte, de exigibilidade de conduta diversa, as justificativas ou mesmo a oposição as referidas críticas sempre coexistiram, com conteúdo semelhante e base comum.

Essas censuras nunca foram transpostas, exatamente, porque a doutrina opositora nunca se satisfez com os argumentos justificantes. Dessa forma, embora constituindo-se teoricamente um importante instrumento de limitação do poder punitivo estatal e de respeito essência do homem, nesse "vai e vem" ou nas "idas e vindas" do conceito de liberdade dentro do sistema penal, figuraram, como verdadeira sombra, as críticas relativas a indemonstrabilidade desse conceito no ponto de vista prático, tendo em vista que todas as justificativas ou contraposições a essas críticas nunca foram tidas como suficientes, capazes, portanto, de superá-las.

É, precisamente, por isso que refletimos sobre as causas supralegais de inexigibilidade de conduta diversa a partir de uma outra perspectiva. Reconhecendo ausência de superação dessas críticas e ainda, diante da incansável tentativa de parte da doutrina responsável pela lapidação da teoria do crime atual de justificar ou de se contrapor às mesmas, inferimos que resta necessário fazer ponderações a partir de um outro viés.

Nesse diapasão, por entender que, considerando a admissão de causas supralegais, é impossível se estabelecer critérios precisos para o reconhecimento das referidas causas, o que desemboca na impossibilidade de caracterização exata e, portanto, capaz de conferir previsibilidade dos casos concretos, julgamos que a delineação da exigibilidade de conduta diversa, tida como necessária em um Estado Democrático de Direito, ocorre a partir da compreensão acerca da funcionalidade desse conceito no sistema penal vigente.

Isso, não por entender que a heterogeneidade das decisões do Poder Judiciário brasileiro seja desimportante, posto que, como dito em linhas anteriores, trata-se de um problema grave e de consequências extremamente negativas. Em verdade, esse mudança de rumo ocorre pela reconhecimento da impossibilidade de se "etiquetar" situações onde há 
inexigibilidade de conduta diversa e por se entender que é possível conferir, satisfatoriamente, homogeneidade às decisões do poder judiciário a partir da percepção acerca da necessidade, da utilidade e da funcionalidade de institutos dessa natureza dentro do sistema penal.

Segundo acreditamos, é a partir da compreensão desses fatores que é possível encontrar os contornos satisfatórios desse instituto. A clareza acerca de todos esses motores, traz como consequência a aptidão para verificação e, claro, fundamentação acerca da adequação da decisão que considera existente ou inexistente a exigibilidade concretamente.

Para entender o papel e a operatividade da inexigibilidade de conduta diversa dentro do sistema penal, tomamos por base os estudos de Tércio Sampaio Ferraz Junior, mais especificamente, a sua teoria sobre ideologia e as chamadas "regras de calibração".

No entanto, por entendermos ser imprescindível para completa compreensão desses institutos, inicialmente, este trabalho expõe as bases que Ferraz Júnior utiliza a construção da sua teoria para, então, se debruçar sobre as suas considerações sobre as "regras de calibração" e outros aspectos relacionados, a fim de, definitivamente, associar sua teoria ao problema desta tese.

É que a compreensão sobre a função da dogmática jurídica e do funcionamento do sistema jurídico é vista como fundamental para se compreender os motivos da exigibilidade de conduta diversa ser estabelecida com os moldes atuais, o papel desempenhado por esse instituto dentro do sistema penal e, mais além, aponta um caminho para análise crítica dos casos em que se discute existência ou inexistência desse instituto, via esta que, caso seja reconhecida, é capaz de reduzir a níveis satisfatórios a já referida insegurança atual desse terreno.

\section{A ABSTRAÇÃO DO CONCEITO DE EXIGIBILIDADE DE CONDUTA DIVERSA COMO MECANISMO DE INTERAÇÃO}


A constituição atual da exigibilidade de conduta diversa e a inerente abstração desse conceito, o que é justificado pela impossibilidade de se prever todas as possibilidades concretas em que não existe liberdade ao agente entre praticar ou se abster uma conduta ilícita, não é estranha à percepção deste autor acerca da complexidade das relações sociais atuais e dos seus reflexos no sistema jurídico.

A abstração ou certo grau de incerteza sobre os seus contornos que existe no sistema jurídico penal em relação à exigibilidade de conduta diversa, a priori, de modo geral, além de tolerável, pode ser considerado necessário para se viabilizar o que Ferraz Júnior chama de interação. Por sua vez, essa interação ocorrerá de forma satisfatória ou não a depender do desempenho da dogmática em relação ao cumprimento do seu papel como instrumento mediador entre a generalidade das normas e a singularidade dos casos concretos.

O que queremos enfatizar, desde já, é que os problemas decorrentes do estabelecimento de instituto com contornos de certo modo indefinidos, com grau de abstração, não é o que determina a sua inadequação, mesmo em se tratando do sistema penal e de um instituto com a importância, inclusive simbólica, da culpabilidade. Esse grau de abstração além de possível deve ser encarado como um fenômeno natural ante a complexidade das relações sociais atuais, notadamente, quando se trata de um instituto com tal natureza.

De outro lado, não se pode admitir que esse grau de abstração traga como consequência a legitimidade ou adequação de uma infinidade de possibilidades de decisões, a já referida heterogeneidade ou disparidade das decisões por parte de uma mesma entidade.

Pois bem, a dogmática jurídica é o instrumento capaz de conferir a racionalidade exigida para o funcionamento do sistema jurídico em casos como esse. É ela, ou melhor, a sua compreensão ao analisar os casos concretos, que vai outorgar consistência a decisão do caso concreto, funcionando, assim, como verdadeiro instrumento mediador entre a referida generalidade normativa e um dado caso concreto. 
De forma geral, o Direito é visto como uma estrutura que define os limites e as interações da sociedade e, como estrutura, é indispensável por possibilitar uma estabilização de expectativas nas interações, ${ }^{15}$ congruentemente generalizadas.

Junto com a escassez de atenção, coloca-se, do mesmo modo, o problema de se justificar a validade das normas pelo consenso, tese comum entre os juristas e sociólogos. No entanto, pode-se dizer que a função das instituições não está no alcance do consenso de fato, mas na economia do consenso, ou seja, não está na produção do consenso, mas na poupança que, em regra, é alcançada por meio de uma antecipação do consenso na expectativa que, por sua vez, passa a ser um suposto e não necessita mais ser questionada concretamente em cada caso. Nesse sentido, as instituições tem um papel muito próximo ao do Direito como simbolismo, sendo a sua permanência uma espécie de mito que, se tornando consciente, pode perder a sua força. Assim, quanto mais complexa a sociedade, menor a chance de consenso fático, maior a necessidade de ficções institucionais a respeito do consenso, maior a necessidade política no sentido de técnica capaz de manipular a escassez do consenso (FERRAZ JÚNIOR, 1998, p. 110-111).

Ocorre que as normas e ideia de instituição podem ainda ter muitos sentidos. Existem expectativas a respeito de certos conteúdos significativos que se espera que tenham prevalência caso haja a existência de um conflito. O controle dessa complexidade real e de sentido, segundo Ferraz Júnior (1998, p. 112-113), deve ser feito por meio de diversos mecanismos denominados de centros ou núcleos significativos. Como os valores são centros significativos por demais abstratos, socialmente eles tendem a ser ideologizados, sendo as ideologias avaliações de valores que

15 "Comportar-se é estar em situação com os outros, os endereçados das mensagens. Estes também estão em situação. Donde comportar-se é, na realidade, a troca de mensagens. Esta troca de mensagens é o que é o elemento do sistema social propriamente dito, a interação." (FERRAZ JÚNIOR, 1998, p. 102) 
lhes dão um caráter programado e hierárquico, pondo-os como fins racionais da conduta, limitando-lhes, assim, a variabilidade semântica.

Resume dizendo que através da normas dá-se às expectativas duração, independentemente do fato de que, de tempos em tempos, elas sejam desiludidas. Pela institucionalização há a suposição do consenso, independentemente do fato de que alguns não estejam de acordo. Por meio dos centros significativos, garante-se a unidade e conexão de sentido das expectativas, independentemente do fato de que, concretamente, haja diferença entre elas e o conteúdo. Nestes termos, o Direito surge como uma generalização congruente e dinâmica destes três mecanismos, possibilitando socialmente, uma imunização simbólica de certas expectativas contra fatos em termos de que podemos atuar de modo indiferente a eles (indiferença controlada). Acrescente-se que, na dimensão social, nem todas as possibilidades de institucionalização são juridicamente viáveis (necessidade de seleção das generalizações congruentes), assim, o Direito está ligado a procedimentos institucionalizáveis por meio de normas, através das quais as institucionalizações se tornam socialmente viáveis, ${ }^{16}$ funcionando, dessa forma, como mecanismo que coordena de modo congruente os mecanismos "norma, institucionalização e instrumentos identificadores de sentido". O Direito não é apenas norma, instituição ou sentido, é a combinação dos três, ou seja, é como denominamos as expectativas normativas de comportamento generalizadas congruentemente em relação a instituições e a identificação de sentido. E, a função da dogmática é justamente, servir como mecanismo de viabilização do Direito na medida em que atua como veículo de alta abstração, capaz de proporcionar uma congruência estável entre os mecanismos de controle social, mesmo quando, aparentemente, eles não e afinam, viabilizando as condições do juridicamente possível (FERRAZ JÚNIOR, 1998, p. 114-116).

${ }^{16} \mathrm{Na}$ dimensão conteúdo, o Direito exerce a sua função seletora, posto que nem todos os programas, papéis, valore ou pessoas, são juridicizados. 
Mesmo assim, é importante refletir o Direito vigente em uma dada sociedade, é mais um conjunto de símbolos e ideias não coerentes, que apresentam sua incoerência ao homem comum exatamente quando este é parte num processo judicial (momento em que é sentido o peso da insegurança). Seu êxito como força unificadora depende da concessão de um significado efetivo à ideia de um governo do Direito como algo unificado e racional, papel desempenhado pela dogmática jurídica. A dogmática jurídica funciona como uma caixa de ressonância das esperanças prevalecentes e das preocupações dominantes dos que creem no governo do Direito acima do arbítrio dos homens, ou seja, tem por objetivo erigir uma espécie de empíreo lógico, onde os ideais contrapostos apareçam como convergentes, demonstrando, dessa forma, que o Direito é, a um só tempo, seguro e elástico, justo e compassivo, economicamente eficiente mas moralmente equitativo, digno e solene mas ao mesmo tempo funcional e técnico. É exatamente por ter essa missão que a dogmática sente a necessidade de fazer gestos de reconhecimento para as variadas técnicas de todos os ramos do saber relacionados ao comportamento humano, reinterpretando-as de modo calibrado, de acordo com os seus objetivos voltados para as regras constituintes da ordem, se revelando, assim, como uma tecnologia que tem, para os que não conhecem, aspectos de um rito cerimonial, os quais respeitam como uma busca constante dos princípios da coerência jurídica (FERRAZ JÚNIOR, 1998, p. 175 e 176).

Todas essas observações iniciais sobre a forma com que Ferraz Júnior percebe o funcionamento do sistema jurídico, como dito em linhas anteriores, são indispensáveis para a exata apreensão da parte da sua teoria que mais nos interessa, por ter uma ligação ainda mais próxima com a questão da interpretação da ideia de exigibilidade de conduta diversa por parte do Poder Judiciário brasileiro.

Servem de pano de fundo para a importante questão relativa à ideologia e valor, elementos determinantes em relação a apreciação acerca da existência ou inexistência da exigibilidade de conduta diversa pelo judiciário. Como dito, muitas vezes implicitamente, toda decisão dessa 
natureza, antecipadamente, aprecia os valores envolvidos em uma dada situação e, necessariamente, naquele caso concreto, decide que certos valores se sobressaiam em detrimento de outros.

Ferraz Júnior demonstra em sua teoria que isso não pode ocorrer de forma aleatória para que a decisão seja entendida, de modo geral, como adequada. É, precisamente, essa compreensão acerca dos fatores que devem ser levados em consideração para que haja a constatação de que uma decisão é adequada, que, por sua vez, exige uma reflexão acerca do funcionamento do sistema jurídico penal, sobre a forma apropriada de se examinar, diante de um caso concreto, a existência da exigibilidade de conduta diversa.

\section{A EXIGIBILIDADE DE CONDUTA DIVERSA COMO INSTRUMENTO DE INTEGRAÇÃO DE VALORES}

Sobre a ideia de valor e de ideologia, inspirado nas ideias de Viehweg, Ferraz Júnior (1998, p. 177 e 178), inicialmente alerta para o fato de que a dogmática constrói teorias com função social, em busca de criar condições para decidir conflitos com um mínimo de perturbação, detém características como intenção holística, arranjos internos e uso declarado ou encoberto de valores que apontam para certos fundamentos de caráter ideológico. Substitui, com certa facilidade, o saber pelo crer, o normativo pelo criptonormativo. Portanto, a dogmática é um pensamento tecnológico e que, por isso, está intimamente relacionada à questão da decidibilidade, o que não se confunde com a ideia de que o verdadeiro esteja daí completamente excluído. $\mathrm{Na}$ realidade, o discurso dogmático não é meramente informativo (o emissor não se limita a comunicar a informação sem se preocupar com o receptor), mas sim eminentemente persuasivo, visto que o emissor tem a pretensão de que a sua informação seja acreditada pelo receptor, ou seja, objetiva despertar uma atitude de crença. Trata-se se um discurso com a finalidade de motivar condutas, embora não se confunda com discursos prescritivos, onde os qualificativos verdadeiro e falso 
carecem plenamente de sentido. Por sua vez, a verdade entra no discurso persuasivo como instrumento de motivação e não como pura informação e, ao colocar-se a serviço da motivação, ela corre o risco de encobrimento ideológico que passa, então, a dominá-la. Assim, muitas vezes, a dogmática coloca a verdade "entre parênteses" e se preocupa mais com o verossimilhante, ou seja, não exclui a verdade, mas ressalta como fundamental a versão da verdade (e da falsidade).

É exatamente por isso que não se pode deixar de reconhecer a importância das avaliações do texto dogmático. Por se tratar de um discurso mais persuasório do que informativo, está sempre relacionado à interesses posto que a persuasão é um sentimento que se funda em interesses ${ }^{17}$ e, a principal forma de manifestação de interesses, é o valor. ${ }^{18}$ Nesse sentido, manifestando interesses, valores chegam a ser considerados entidades, compondo um sistema em si mas com funções interacionais, visto que valem para comportamentos interativos em termos de um processo seletivo das informações em curso. Esses processos seletivos são de duas ordens: modificativa (o valor controla as reações possíveis do receptor no sentido de que uma exigência de que elas venham se adaptar a ele, assim, os comportamentos são tomados como variáveis e o valor, colocado como invariante, os seleciona) e justificativa (processo seletivo inverso, posto que representa um movimento do comportamento para o valor). Apesar de conceitualmente haver essa distinção, já que no primeiro caso as informações se afastam ao valor e, no segundo, o valor se adapta às informações, na prática é difícil fazer tal distinção posto que o discurso

17 Vinculações intersubjetivas nas quais se fundam os procedimentos persuasórios, podendo-se falar em desinteresse omo desvinculações nas quais se fundam procedimentos dissuasórios. São disposições para interagir, podendo, por meio do discurso, ser reforçados, suprimidos, modificados, escondidos, etc. (FERRAZ JÚNIOR, 1998, p. 179)

18 Para Ferraz Júnior (1998, p. 179)," os valores são símbolos de preferência para ações indeterminadamente permantes, ou seja: fórmulas integradoras e sintéticas para a representação do consenso social." 
persuasivo utiliza estratégias objetivando a credibilidade que podem esconder a real função do valor, dando por exemplo a impressão de que estamos modificando quando estamos justificando (FERRAZ JÚNIOR, 1998, p. 181).

A existência de valores no texto da dogmática faz dele um discurso eminentemente persuasivo, cuja força se encontra na objetividade que pretendem expor. Os valores em jogo, não são os do autor, mas os da comunidade. Entretanto, para exercer essa função persuasiva, esses valores devem ser neutralizados que, por sua vez, consiste e um processo pelo qual os valores parecem perder suas características intersubjetivas na medida em que dão a impressão de valer independentemente de situações e contextos. Esta referida neutralização é obtida através da ideologia, conceito funcionalizado por Ferraz Júnior, que o admite como axiológico, posto que a linguagem ideológica é também valorativa. Segundo o autor, enquanto os valores em geral constituem critério de avaliação de ações, a valoração ideológica tem, por objeto imediato, os próprio valores, com uma qualidade pragmática diferente posto que, enquanto os valores são expressões abertas, reflexivas e instáveis, a valoração ideológica é rígida e limitada, atua no sentido de que a função seletiva do valor no controle da ação se torna consciente, ou seja, a valoração ideológica é uma metacomunicação que estima estimativas, valora as próprias valorações, seleciona as seleções, ao dizer ao interessado como deve vê-las. É uma valoração sui generis posto que, de certa forma, se desacredita como tal, pois sendo uma valoração de valores, ela garante o consenso daqueles que precisam manifestar seus valores, assegurando-lhes a possibilidade de expressão. Assim, os valores se tornam comunicáveis mas, ao mesmo tempo, se estabelece uma instância que neutraliza as valorações, de certo modo pervertendo, uma vez que lhe retira a abertura (FERRAZ JÚNIOR, 1998, p. 182 e 183).

Como se percebe, a ideologia funciona, no discurso dogmático, como um elemento estabilizador. Valorando os próprios valores ela os fixa, quer justificando sua função modificadora, quer modificando a sua função justificadora. Dessa forma, a ideologia exerce uma função de suma 
importância que é organizar os valores, possibilitando a sua sistematização, a construção de certas hierarquias o que, em última análise, resulta na possibilidade de integração de interesses e de sua realização, bem como na possibilidade de sistematização do próprio discurso dogmático. Ela calibra o sistema dogmático na medida em que só por ela é possível determinar, num certo contexto, que tipo de integração ou unidade o mesmo deve possuir como um todo, para que as suas proposições constituam cadeias válidas e, consequentemente que tipo de autoridade deve ser presumida como legítima.

Há ideologia sempre que ocorre uma neutralização de valores, ou seja, as ideologias são sistemas de valorações encobertas. A dogmática se vale de procedimentos específicos como recurso ao argumento da autoridade representado por certos autores renomados que são utilizados de modo deslocado do seu contexto teórico, jogando o pensamento de um lado para o outro, criando a impressão de que as conclusões decorrem dos autores citados, quando, em verdade, elas resultam das valorações camufladas daquele que argumenta. Ferraz Júnior (1998, p. 1985) explica que:

Podemos encobrir valorações quando, por exemplo: a) substituímos fórmulas valorativas por fórmulas neutras, como ocorre com a noção de normas fundamental em Kelsen, termo que encobre valoração fundamentais, dando ao sistema jurídico a imagem de um sistema formalmente objetivo; ou: b) quando escondemos a presença inevitável do emissor de uma valoração, dando a impressão de que se trata de uma proposição sem sujeito, caso de expressões do tipo: ideia de Direito, fontes de Direito.

Finalmente, é importante acrescentar que esse caráter ideológico da dogmática faz com que seu discurso não se confunda com as sistematizações e regularidades empíricas do comportamento, nem com generalizações destas regularidades, nem mesmo, com um conjunto de regras de natureza lógico-formal. Por ser ideológico, ele atua como um 
elemento calibrador do próprio Direito, enquanto uma estrutura de controle de comportamentos "um sistema em que cada agente age de certo modo porque os demais agentes estão legitimamente seguros de poder esperar dele um tal comportamento" (FERRAZ JÚNIOR, 1998, p. 187 e 188).

A nosso ver, esse ponto da teoria de Ferraz Júnior é bastante esclarecedor em relação à reflexão relativa às constantes exigências no sentido de se definir critérios para se considerar existente ou inexistente a ideia de exigibilidade de conduta diversa em um caso concreto ou mesmo de se apresentar contornos mais acentuados em relação ao instituto, isso, como visto, em face do problema da heterogeneidade das decisões do poder judiciário em relação ao tema.

Mesmo considerando que essa heterogeneidade constitui um problema grave, entendemos que a definição de quaisquer critérios fixos para se identificar os casos de inexigibilidade, além de insuficientes, dada a complexidade do mundo em que vivemos, constitui mais um recurso argumentativo na tentativa de encobrir valorações com o objetivo de transmitir a impressão de que se trata de uma proposição sem sujeito, de uma decisão formal, objetiva e, portanto, plenamente racional.

Inevitavelmente, em se tratando de uma decisão sobre a exigibilidade de conduta diversa, não há como o julgador tomar por base, como fruto da dogmática jurídico-penal, uma sistematização ou regularidade empírica de comportamentos, nem generalizações destas regularidades, nem mesmo, um conjunto de regras de natureza lógicoformal.

Já relatamos que todas as decisões que se debruçam sobre a questão da exigibilidade de conduta diversa, mesmo que explicitamente não reconheça, aprecia valores postos em jogo. A vida, a segurança, o patrimônio, a autonomia sobre o próprio corpo, família e muitos outros valores são exemplos disso. E, como dito, toda decisão dessa natureza também, inevitavelmente, determina que em um dado caso concreto, certos valores devem se sobressair em detrimento de outros. 
Entendemos a única forma de se fazer um juízo acerca da adequação ou inadequação de uma decisão dessa natureza, em relação ao sistema jurídico-penal, é por meio da sua verificação de sua correspondência com o que Ferraz Júnior denomina de ideologia.

Nesse diapasão, a fim de se fazer um juízo crítico com relação a existência da exigibilidade de conduta diversa em um dado caso concreto, muito além de uma análise puramente normativa, objetiva ou mesmo formal, o julgador deve atentar para os valores postos em jogo em relação a ideologia presente no discurso dogmático-penal.

A adequação de uma decisão penal, notadamente em relação a um institutos com contornos justificadamente mais pálidos, como é o caso em exame, deve, impreterivelmente, verificar a existência de congruência com a ideologia presente no discurso dogmático-penal. Isso, para que a dogmática-penal atinja o seu principal objetivo que é aquilo que se considera como consenso, ou melhor, que em uma decisão haja o mínimo de perturbação ao sistema jurídico como um todo.

Uma decisão penal que, ao se debruçar acerca da existência de exigibilidade de conduta diversa, é consciente de que trabalha com valores que, por sua vez, refletem interesses dentro de discursos eminentemente persuasórios, deve filtrar esses valores a partir de uma leitura da ideologia presente na dogmática penal, o que contribui para a estabilidade do sistema jurídico-penal, evitando, assim, a existência da heterogeneidade das decisões relativas a esse tema, que é de todo grave, como visto anteriormente.

Consideramos que a heterogeneidade presente nos precedentes que versam sobre a ideia de exigibilidade de conduta diversa, revelam a insegurança do Poder Judiciário em relação a definição desse instituto e isso, não por falta de critérios formais estabelecidos, mas sim, por falha de consciência acerca do funcionamento do sistema penal.

Há a falta de consciência de que os discursos penais trabalham com interesses baseados em valores. Que o objetivo de uma decisão não é dizer a verdade, utilizada muito mais como instrumento de motivação, mas sim, imprimir convergência de valores, conferindo, assim, a segurança do 
Direito. Preocupa-se muito mais, portanto, com a verossimilhança que, por sua vez, é capaz de conferir mínima perturbação ao sistema vigente.

A decisão adequada, portanto, é aquela que parece homogênea ante as demais, convergente com o discurso dogmático que, em essência, é ideológico. Daí o incômodo gerado pela seleção aleatória de valores prevalecentes em detrimento de outros. Decisões como essa, em grande número como é o caso em tela, tendem a perturbar o sistema, à desestabilizá-lo.

Ainda sobre a teoria de Ferraz Júnior, é interessante observar que, segundo ela, é por meio da ideologia que as funções modificadora e justificadora, de per si, se tornam compreensíveis e, sobretudo, a sua combinação no discurso se faz mais transparente. (FERRAZ JÚNIOR, 1998, p. 161)

De fato, a valoração ideológica constitui um elemento importante para o uso do valor no discurso da norma. Valores estabelecidos, na sua função modificadora, como invariantes, têm de ser compreendidos abstratamente, para deixar em aberto as diversas possibilidades de ação. Isso só pode ser alcançado quando sua "seletividade" interna é dirigida aos comportamentos visados que, por sua vez, de modo variado, podem funcionar como prisma para a seleção de meios apropriados. Porém, a utilização do valor na sua função modificadora pode, em virtude de sua flexibilidade abstrata, gerar dificuldades, no que se refere ao estabelecimento do valor como orientação para ação, ou seja, a expressão sintomática do valor como fim, gera uma insegurança no ouvinte e na função de sinal do discurso. É nesse sentido que a valoração ideológica atua: no sentido de neutralizar programas valorativos ao determinar quais fins, em certas circunstâncias e condições, possibilitam a indicação dos meios e sua justificação, fazendo da função modificadora uma modificadorajustificante. Portanto, o efeito da valoração ideológica é colocar fim na reflexividade dialógica da norma, explicando, assim, o "momento da dogmaticidade" no Direito. A presença da estrutura monológica expressa o domínio dos valores e finalidades valorados ideologicamente, em que se 
permite apenas a discussão técnico-instrumental (FERRAZ JÚNIOR, 1998, p. 162 e 163).

Assim concebido e sistematizado, o discurso da norma deve ser capaz de conferir uma racionalidade que se manifesta na obtenção de proposições verossímeis. Isso significa ver a norma como uma proposição verificável ou falsificável por partes homólogas, portanto, que se legitima por sua capacidade de verdade, condição máxima do consenso.

Quanto mais complexa e significativa é a quantidade de variáveis na práxis jurídica, tanto mais importante se torna também a pressão no mundo circundante, provocando a mútua influência das partes entre si e, assim, mutações internas que escapam do controle do jurista. A depender do grau de instabilidade, gera-se riscos ao caráter ou natureza sistêmica do discurso da norma.

Entendemos que, dentre os institutos da teoria do crime, a exigibilidade de conduta diversa é dos mais complexos, daí a necessidade ainda mais proeminente de ser realmente compreendido, notadamente, em relação a sua funcionalidade, ao seu papel dentro do sistema penal, sob a dura pena do judiciário produzir decisões heterogêneas sobre esse respeito.

Segundo Ferraz Júnior (1998, pp. 183 e 184), essa questão não é de somenos, previsto que a incerteza e indecisão no seu tratamento traz consequências importantes ao Direito. Diz que, de início, é necessário refletir sobre a natureza estrutural do discurso da norma, analisando o sentido da relação entre as funções valorativas e ideológicas, o que permitirá compreender melhor a sua complexidade, sem ter que apelar para uma interpretação como discussão-com (científica), com todos os inconvenientes daí decorrentes. A análise das funções valorativas (modificadora e justificadora) do discurso da norma é ligada ao seu caráter de discussão-contra. É um discurso persuasivo que visa conquistar um ouvinte reativo. Daí pode-se entender a função justificadora do valor, na medida em que o discurso da norma procura expressar (função sintomática) uma informação tida como "redundante" por passar do pressuposto de que o ouvinte "já sabe e quer" aquilo que diz, procurando integrar-se no seu 
sistema de expectativas e exigindo dele uma concordância com o que já havia concordado conscientemente ou não (função de sinal). Nesse sentido, o discurso é ficticiamente informativo e inovador, procurando simplesmente "atiçar as expectativas" do ouvinte. O movimento do discurso da norma é, assim, "aparente”, fazendo com que o ouvinte acredite que há uma nova decisão mas, no fundo, parte de um universo já aceito e, essa aceitação, sendo camuflada, não deve ser entendida com um certum monológico, pois se trata de um recurso dialógico, de persuasão.

Como se percebe, a função da ideologia no discurso da norma é de neutralização do valor, na medida em que por meio dela valoramos as próprias valorações. É, nesse sentido, o universo dos valores possíveis de um indivíduo, de um grupo, de uma cultura. Contudo, o referido universo só pode ser conhecido na medida em que é dialogicizado (são comunicados), por isso, só identificamos a ideologia quando usamos os seus valores. Esse papel da ideologia só aparece quando as valorações são possíveis. Por sua vez, a ideologia interage com valorações, limitando-lhes o alcance, de onde se pode concluir que uma valoração das valorações do discurso da norma é correlata à variação da ideologia, na medida em que a ideologia incorpora, ao neutralizar, as funções valorativas, ou seja, fixa as premissas do discurso da norma, tornando a sua dialogicidade estilizada e limitada, O discurso ideológico é, portanto, adaptável, harmonizável, suficientemente elástico, de caráter eminentemente holístico. Por isso, uma verdadeira transformação nas expectativas ideológicas só é efetiva quando capaz de ser traduzidas em mensagens que subvertam as expectativas dos valores e vice-versa (FERRAZ JÚNIOR, 1998, pp. 187 e 188).

Essa característica do discurso ideológico merece ser também frisada em relação à discussão sobre a ideia de exigibilidade de conduta diversa uma vez que se apresenta como espaço ou mesmo caminho para a atualização ou renovação desse conceito, mais especificamente, das situações, no contexto atual, capazes de eliminar o dever de comportar conforme o direito. 
É nesse sentido que podemos considerar que esse espaço interpretativo de institutos jurídicos, tais como a exibilidade de conduta diversa, funcionam como um recurso ideológico do discurso normativo, viabilizam o discurso judicial, como discurso persuasivo, partidário e que busca uma decisão favorável, encobrem o conflito da legalidade-equidade, dando ao intérprete condições de apresentar fatores extra positivos como positivos ou positiváveis e ainda, permitem ao discurso da norma uma sistematização (FERRAZ JÚNIOR, 1998, p. 190).

A função seletiva do valor, nesse diapasão, apresenta-se no discurso normativo como instrumento de controle do comportamento. Trata-se se instrumento persuasório, com foco em um ouvinte reativo que deve ser conquistado.

Uma decisão que versa sobre a existência de exigibilidade de conduta diversa, em um dado caso concreto, consciente ou inconscientemente, seleciona valores. Indo mais além, verifica-se que, por se tratar de um discurso persuasório, a decisão, com essa seleção, almeja conquistar um ouvinte potencialmente reativo, despertando uma atitude de crença, tudo com o objetivo de preservar o sistema jurídico.

Assim, ao ditar que em família ou vida, por exemplo, são relevantes ao ponto de justificar a ausência de liberdade do agente, ou melhor, a ausência do dever de agir conforme o direito em um dado caso concreto, o julgador, muito além da análise da existência de liberdade, do ponto de vista pessoal ou subjetivo do agente, tem por objetivo que essa conclusão seja aceita sem questionamentos pelo ouvinte potencialmente reativo a que ela se destina direta ou indiretamente, contribuindo, assim, para a unidade das expectativas, para a estabilidade do sistema jurídicopenal.

Apesar de reconhecer que nos discursos normativos, como discursos heterológicos, há o uso de técnicas ou estratégias com o fim de persuadir, dificultando a identificação e distinção das funções modificadora e justificadora, entendemos que sobre as decisões que tratam da existência 
de exigibilidade de conduta diversa, há, comumente, tentativa de transmitir a existência da função modificadora.

A função modificadora persuade na medida em que reestrutura ao máximo aquilo que já é conhecido. O discurso normativo parte aqui de premissas já adquiridas mas, para questioná-las, submete-as ao crivo crítico. Expressa algo inusitado, sendo, nesse caso, efetivamente informativo, pressupondo que o ouvinte não sabe e nem quer saber aquilo que se diz, visando a uma reação positiva de aceitação, mas, como a reação pode ser de contestação, o objeto mantém o seu caráter de dubium conflitivo. É exatamente por isso que, de forma geral, quando o valor possui função modificadora há um enriquecimento do universo de expectativa (FERRAZ JÚNIOR, 2003, p. 154).

Nas decisões que versam sobre a existência de exigibilidade de conduta diversa, o que se busca transmitir, é que o valor liberdade é colocado como invariante e, concomitantemente como critério para a seleção de comportamentos diversos. Em razão do valor liberdade, comportamentos são selecionados, portanto, funciona como prisma, como projeto modificador e demarcatório dos comportamentos aos quais se dirige.

Ocorre que, nas referidas decisões, após a adoção da função modificadora, há seguidamente, a presença da função justificadora a fim de legitimar a seleção de certas condutas baseada em juízos também de valor, reduzindo, assim, a complexidade conflitiva por meio do discurso. Conferese, dessa forma, a racionalidade ao processo de seletividade que existe em relação aos valores postos em jogo.

Como elemento estabilizador, a ideologia atua no discurso normativo valorando valores, fixando-os, quer justificando a sua função modificadora, quer modificando a sua função justificadora. Assim, a ideologia exerce a função de suma importância de organizar os valores, possibilitando a sua sistematização, a construção de hierarquias o que, em última análise, resulta na possibilidade de integração de interesses e de sua 
realização, bem como a possibilidade de sistematização do discurso normativo.

Nesse diapasão, acreditamos que a exigibilidade de conduta diversa funciona no sistema jurídico-penal como mecanismo de coesão, de redução da complexidade social já esplanada por possibilitar, notadamente dada a sua essência e também a fluidez da sua definição, a neutralização de valores por meio da ideologia, sua sistematização, garantindo o consenso almejado e de suma importância para estabilidade e, portanto, para a própria garantia de funcionamento do sistema penal.

Nesse sentido, a análise sobre a adequação de uma decisão que se debruça sobre a questão da exigibilidade de conduta diversa, considera, muito além da existência ou inexistência da liberdade concreta (vista do ponto de visto subjetivo) ou critérios normativos formalmente estabelecidos, os valores postos em jogo em relação a ideologia que dá coesão ao sistema jurídico-penal, garantindo a tão almejada estabilidade pela ausência de defraudação de expectativas.

Nesse sentido, a definição normativa de forma difusa da exigibilidade de conduta diversa no sistema jurídico-penal pode e deve funcionar, positivamente, como técnica do discurso normativo, posto que, no momento em que confere espaço para a presença de uma avaliação de natureza ideológica, funciona como instrumento para a calibração do sistema, como uma "regra de calibração".

Essa fluidez ou abertura normativa confere espaço para delimitação por parte do julgador, ou seja, do ator que é capaz de filtrar ou mesmo captar a ideologia atual, visto que o discurso ideológico é adaptável e, portanto, passível de atualização. A partir do cumprimento do seu papel, o judiciário, dita valores como atuais, formando nova cadeia válida, ao mesmo tempo que contribui para a estabilidade do sistema jurídico-penal.

Como já se pode inferir, a justificação da função modificadora em uma decisão que trata da exigibilidade de conduta diversa reflete, exatamente, os limites dessa causa de exculpação. É que nesse processo, há uma seletividade de base ideológica dos valores postos em jogo, momento 
em que são racionalmente definidos quais valores devem prevalecer em detrimento de outros, formando, outrossim, cadeias normativas válidas que, por sua vez, nutrem a ideia de coesão do sistema, do consenso.

Dessa forma, é a partir dessa leitura de natureza ideológica, da compreensão desse processo, que uma decisão que se debruça sobre a exigibilidade de conduta diversa deve ser avaliada, no sentido de ser considerada adequada ou inadequada.

À propósito, é, exatamente, por meio dessa adequação, da neutralização do discurso normativo através da ideologia, que garante-se o consenso, a redução de questionamentos. Concomitantemente, concorre-se para a estabilidade do sistema jurídico-penal, dando-lhe mais força pela maior aparência de coesão, de imperatividade.

Essa percepção acerca da exigibilidade de conduta diversa, além de ser capaz de tornar possível a diminuir a complexidade conflitiva atual satisfatoriamente, de forma racional, como o sistema exige, também torna evidente o importante papel que esse instituto exerce dentro do sistema jurídico-penal, uma vez que funciona como verdadeiro mecanismo de coesão dentro do sistema, reduzindo a complexidade daquele que se apresenta como conceito o mais complexo da definição analítica de crime: a culpabilidade.

\section{CONCLUSÃO}

Reconhecendo ausência de superação das críticas sempre presentes ante o apontamento de critérios para identificação de causas supralegais de exigibilidade de conduta diversa, inferimos que resta necessário fazer ponderações a partir de um outra perspectiva, que parte da análise do funcionamento do sistema penal e do papel desenvolvido pela ideia de exigibilidade de conduta diversa.

Dessa forma, é por entender que se afigura como inviável o estabelecimento de critérios exatos para o reconhecimento das referidas 
causas, tendo em vista a impossibilidade de se prever, antecipadamente, os casos concretos, julgamos que a delineação da exigibilidade de conduta diversa, tida como necessária em um Estado Democrático de Direito, ocorre a partir da compreensão acerca da funcionalidade desse conceito no sistema penal vigente.

Sobre o funcionamento do sistema e de institutos com as características a exigibilidade de conduta diversa, nos valemos dos estudos de Tércio Ferraz Júnior. A partir da compreensão das suas obras, depreendemos que a fluidez da ideia de exigibilidade de conduta diversa não necessita de ser estancada, mas sim, utilizada em benefício do sistema penal.

Entende-se, por conseguinte, que a amplitude, fluidez ou mesmo abertura do conceito de exigibilidade de conduta diversa, permite a ação da dogmática como instrumento mediador entre a generalidade da norma e a decidibilidade dos conflitos que, por sua vez, se vale de um conteúdo ideológico, o que possibilita uma constante atualização do discurso normativo.

É a dogmática que deve, nesse sentido, a partir da fundamentação das decisões, fixar o juridicamente possível, por meio de uma leitura ideológica, uma vez que as normas, isoladamente, são limitadas em relação à identificação das possibilidades de variação dos comportamentos.

Como é função da dogmática apreciar, tomando por base a ideologia, as possibilidades de decisão, a amplitude da definição de exigibilidade de conduta diversa é propícia a esse papel, permitindo, assim, à dogmática operar como elemento estabilizador, por meio de um discurso persuasório que desperte no ouvinte potencialmente reativo uma atitude de crença, de concordância, fortificando, dessa forma, o sistema jurídico-penal.

A análise detida acerca do percurso desse caminho pelos julgadores, em uma dada decisão sobre a exigibilidade de conduta diversa, é o que nos permite concluir sobre a consistência ou inconsistência da mesma. Assim, a desejada coerência jurídica ou homogeneidade das decisões deve 
ser alcançada partindo da compreensão acerca da necessidade de afinidade ideológica.

É por meio dessa análise crítica acerca da adequação na decisão judicial que se debruça sobre a questão da exigibilidade de conduta diversa e da ideologia que ali deve estar presente, que se garante satisfatoriamente a neutralização desse discurso, a redução de questionamentos, o consenso. Concorre-se, pari passu, para estabilização do sistema-penal, conferindo-lhe mais força por imprimir coesão e imperatividade.

Funciona essa leitura de natureza ideológica ou mesmo a compreensão de todo esse processo de análise de cunho ideológico do discurso normativo, portanto, como fatores que devem nortear o julgador no momento de se apreciar a existência ou inexistência de exigibilidade de conduta diversa em um dado caso concreto a ele apresentado.

Como se percebe, ante o problema da heterogeneidade das decisões judiciais que analisam a exigibilidade de conduta diversa em casos concretos, a valoração ideológica funciona como peça chave.

É que uma decisão dessa natureza, se fortalecida ideologicamente, contribui para que o sistema jurídico seja visto como convergente, como uma ordem congruente, harmônica, atingindo o principal objetivo da dogmática que é resolver questões sem que haja uma perturbação prejudicial ao sistema, ou seja, sem desestabilizá-lo.

Nos casos onde se questiona a existência de exigibilidade de conduta diversa, há necessariamente, valores em comunicação. É, exatamente, esse hiato conferido pela fluidez do seu conceito, o espaço propício e necessário para a neutralização desses valores, tarefa atribuída à ideologia.

Por isso, a ideia de exigibilidade de conduta diversa funciona como elemento de calibração do sistema penal. A partir de uma decisão ciente de todo esse contexto, são formadas novas cadeias válidas, gerandose, por conseguinte um conteúdo também informativo.

A definição normativa vaga da exigibilidade de conduta diversa a transforma em verdadeiro instrumento de atualização do sistema jurídico- 
penal. Opera como técnica do discurso normativo, visto que confere espaço para a valoração dos valores, para a presença da ideologia, ou seja, permite que esse instituto funcione como mecanismo de calibração do sistema penal, como "regra de calibração".

Portanto, funciona a ideia de exigibilidade de conduta diversa como uma abreviatura simbólica que serve à integralização concreta de base ideológica, absorvendo ou reduzindo os riscos de uma falha humana no processo decisório, até um grau satisfatório, o que possibilita, ademais, a determinação dos casos de exigibilidade de conduta diversa conforme as exigências de um Estado Democrático de Direito.

\section{REFERÊNCIAS}

AGUADO, Paz M. de La Cuesta. Culpabilidad: exigibilidade e razones para la exculpación. Madrid: Editorial Dykinson, S. L., 2003.

BRANDÃO, Cláudio. “Culpabilidade: sua análise na dogmática e no Direito Penal brasileiro". Revista Portuguesa de Ciência Criminal. Coimbra: Coimbra Editora, 2005.

CARRARA, Franscesco. Programa de Derecho Criminal: Parte General. Vol. 1. Bogotá: Editorial Temis, 1996.

DIAS, Jorge de Figueiredo. Liberdade, culpa, Direito Penal. Coimbra: Coimbra Editora, 2011.

FERRAZ JÚNIOR, Tércio Sampaio. Direito Retórica e Comunicação. São Paulo: Atlas, 2003.

Limonad, 1998.

Função Social da Dogmática Jurídica. São Paulo: Max 
. Teoria da Norma Jurídica. Rio de Janeiro: Forense, 2003.

MELLO, Sebástian Borgens de Albuquerque. Conceito material de culpabilidade. Salvador: Juspodium, 2010.

PUIG, Santiago Mir. Introducción a las bases del Derecho Penal. 2 ed. Buenos Aires: B de F, 2003.

RODA, Juan Córdoba. Culpabilidad y Pena. Barcelona: Bosch Casa Editorial. 1977.

ROXIN, Claus. Derecho Penal: parte general. Tomo I. Madri: ThomsomCivitas, 2003.

A culpabilidade e sua exclusão o Direito Penal. Revista brasileira de Ciências Criminais, ano 12, n. 46, São Paulo: Revista dos Tribunais, 2004.

1981.

. Culpabilidad y prevención em Derecho Penal. Madri: Reus,

WELZEL, Hans. El nuevo sistema del Derecho Penal: uma introducción a la doctrina de acción finalista. Buenos Aires: B de F, 2002. 